\title{
The Construction of Hierarchical Experimental Teaching System of Economics and Management in Research Universities
}

\author{
Yuan Gao* \\ College of Economics and Management \\ Northwest University \\ Xi'an China \\ tutuyuan@163.com
}

\author{
Jun Feng \\ College of Informatics \\ Northwest University \\ Xi'an China \\ fengjun@nwu.edu.cn \\ Min zhang \\ College of Foreign Languages \\ Northwest University \\ Xi'an, China \\ zyzmm@hotmail.com
}

\begin{abstract}
This paper analyzes the existing experimental teaching development mode of economics and management, pointing out that such experimental teaching of economics and management in research universities cannot fully meet the demand of rapid development of social economy for the training of economic management top-tip talents. The experimental teaching of economics and management urgently needs to realize four diffe rent transformations: from single subject verification to comprehensive design, from knowledge succession to research innovation, from traditional method to combination of new technique method, and from indoctrination type to enlightening and discussing experimental teaching type. Based on practical experience of constructing the national experimental teaching demonstration center for many years, this paper puts forward the hierarchical experimental teaching system which integrates verification-based experimental teaching, comprehensive experimental teaching and research-type experimental teaching toge ther to meet the developing goal of rese arch universities and realize the coordinated development of "theory-practiceinnovation" for economic management top-tip talents.
\end{abstract}

Keywords-research-type universities; experimental teaching; tip-top talents

\section{INTRODUCTION}

Research universities, which focus on the dissemination, production and application of knowledge, aim at producing high-level scientific research achievements and training highlevel talents ${ }^{[1]}$. The experimental teaching carried out in research universities is one of core driving forces in the framework of high-level talents training, which is based on the students as the main body and the training of innovation ability as the core, and takes knowledge imparting, ability training, quality improving and coordination developing as teaching goals $^{[2]}$.

Traditional learning process is a kind of successive and sustained learning, which applies to master known and repeated situations. However, in the constantly changing era of

This work was financially supported by the Postgraduate Education and Teaching Reform project of Northwest University (YJG17003). cultural knowledge, scientific and technological information and economic and social development, higher demand has been put forward for academic accomplishment of the tip-top talents of economics and management. Carrying out experimental teaching in research universities is not only the complementary and deepening of theoretical teaching, but also another independent branch of developing students' comprehensive quality and ability. The experiment teaching which centers around "learning" and "living" emphasizes on the combination of class teaching, extracurricular teaching and practical system to realize the coordinated development of 'theory-practiceinnovation" for the training of economic and management talents.

This paper discusses the important role of the experimental teaching in the training of top economic and management talents in research universities, and analyzes shortcomings of existing experimental teaching system in training diversified talents. Combined with the goal of talent training in leading universities, it also explores the effective way of improving college students' subject accomplishment and innovation ability in an all-round way and puts forward a hierarchical experimental teaching system of economics and management to meet the urgent needs for high-level economic management talents.

II. The Present Developing Situation of EXPERIMENTAL TEACHING CONSTRUCTION OF ECONOMICS AND MANAGEMENT

Experimental teaching plays an important role in promoting cultivation of college students' practical ability and innovative spirit and improving the quality of higher education ${ }^{[3]}$. In order to better meet the needs of China's economic and social development and the construction of an innovative country, the Ministry of Education of China launched the construction and evaluation of experimental teaching demonstration centers in institutions of higher education in May 2005, which has greatly 
supported domestic experimental teaching construction of economics and management. As shown in Figure 1, there are 49 experimental teaching centers of economic and management in universities in China were given the title of national experimental teaching demonstration center from 2006 to 2015.

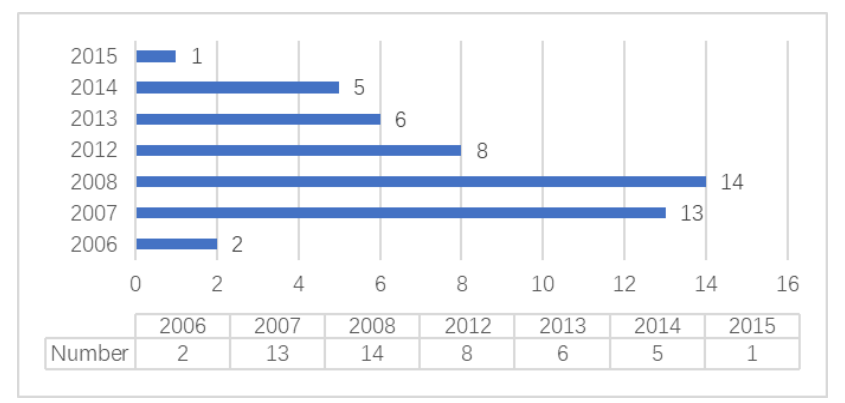

Fig. 1. Summary of Grant of National Experimental Teaching Demonstration Center of Economics and Management

Throughout the construction of domestic experimental teaching of economics and management, its developing process can be summarized from the stage of infrastructure construction to content promotion construction.

\section{A. Stage of Infrastructure Construction}

Since 1980s, in order to meet social demands for economic management talents with modern information technology, the institutes of economics and management in domestic research universities have gradually set up audio-visual education centers, taught students basic computer operation technologies, and developed students' capabilities to use modern information technology means in social and economic survey, economic analysis and practical operation.

\section{B. Stage of Content Promotion}

Around 2000, after 20 years' development, the construction of experimental teaching of economics and management stepped into the stage of content promotion. The main performance was that every research college and university set up specialized laboratories which were based on subjects and oriented by specialties, such as electronic commerce laboratory, financial management laboratory, commercial sand table laboratory, business administration laboratory, etc., and constructed more perfect comprehensive experimental teaching center of economics and management step by step.

\section{ANALYSIS OF EXISTING PROBLEMS IN EXPERIMENTAL \\ TeAching System of ECONOMICS AND MANAgEMENT}

Research universities are at the top level of higher education system. In China, after more than 20 years of development, the experimental teaching in research universities has fully embodied its characteristic of advocating individuation and played an important role in the training of tip-top talents. However, the existing experimental teaching system is still unable to fully meet the practical demand of rapid development of economics and management, and is facing the following four urgent demands of transformation: from single-subject verification to comprehensive design, from knowledge succession to research innovation, from traditional method to combination of new technology, and from indoctrination type to enlightening and discussing type of experimental teaching.

\section{A. Transformation from single-subject verification to comprehensive design}

It changes the long-standing traditional habit that the experimental teaching of main courses mainly just take the verification practice for related knowledge in theoretical teaching process, implements mutual interaction of knowledge points in curriculum content, designs comprehensive analytical research of multidisciplinary interaction along the time axis and space axis dynamic change and provides teaching training from the integration of single-subject knowledge to comprehensive experimental teaching training.

\section{B. Transformation from knowledge succession to research innovation}

Research universities take academic research and talent training as the main goals and attaches great importance to the cultivation of top innovative talents ${ }^{[4]}$. Combining with the research hot spots in the economic society, we set up the project to specialize, in which provides students with topic selection and establishment, economic management data collection, research technical method collection, research work (including the test, the analysis) development, thesis writing summary, so as to achieve the transformation from traditional knowledge succession to independent research and innovation.

\section{Transformation from the traditional method to the combination with new technology method}

The current development of experimental teaching informationization in research universities is still immature, and it will still take some time to achieve the deep integration between information technology and experimental teaching ${ }^{[5]}$. New technologies and methods remain to be brought into the experimental teaching system. During the experimental process, multimedia, economic management data analysis software, Internet and system software technology platform are adopted to improve the students' comprehensive research ability of raising, decomposing and analyzing problems.

\section{Transformation from indoctrination type to enlightening and discussing type}

With the transformation of economic society in China, students' learning motivation presents a trend of diversification and complication and influenced by various factors, such as personal interest, learning attitude, realistic demand ${ }^{[6]}$. Experimental teaching mode needs to change the traditional method of "inculcation-cognition-verification," from the focus of "teaching mode" to the focus of "learning mode ${ }^{\text {r[7] }}$. It is urgent to take students as the main body throughout the teaching process, and adopt the enlightening and discussing experimental teaching mode which can stimulate students' initiative, independent thinking and creative thinking. 


\section{THE CONSTRUCTION OF HIERARCHICAL EXPERIMENTAL Teaching System of ECONOMICS AND MANAGEMENT}

The development level of research universities is an important symbol of the comprehensive strength of national higher education, and its development significantly pushes ahead scientific and technological innovation, knowledge creation, cultural guidance, economic development and social progress. The success or failure and good or bad points of the function performing of research universities directly determine their sense of contribution and influence to national development ${ }^{[8]}$.

With the aim of tip-top talents training in leading universities, the talents trained in leading universities should have broad academic vision, strong innovative awareness and social responsibility ${ }^{[9]}$. Based on many years of practical experience in the construction of national experimental teaching demonstration center, this paper puts forward a hierarchical experimental teaching system. As shown in FIG. 2, the hierarchical economic management experiment teaching system is composed of three complementary and progressive modules, namely, the verification experimental teaching, comprehensive experimental teaching and research experimental teaching, which are throughout the whole experimental teaching.

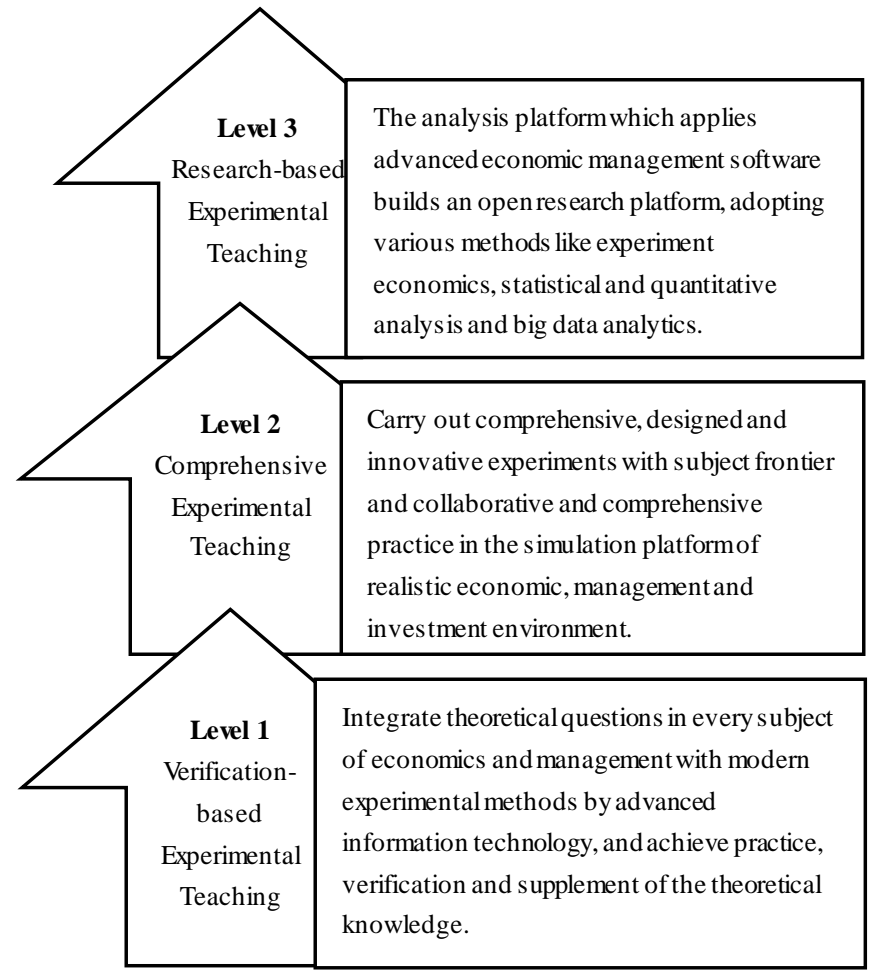

Fig. 2. Hierarchical Experimental Teaching System of Economics and Management

\section{A. Verification-based Experimental Teaching}

The verification-based experimental teaching develops around professional basic courses, and mainly bases on the basic demonstration and verification experiments. The experimental teaching of this level is undertaken by teachers with deep theoretical background, rich teaching experience and strong teaching and research ability.

In verification-based experimental teaching, teachers utilize multimedia technology and econometric software to assist completing the relevant teaching of each professional basic course, and realize the high-quality resource sharing of courses, which effectively integrates the experimental methods of modern economics and the advanced management methods based on information technology into the theory teaching and improve scientificity. Students strengthen the perceptual awareness of knowledge points, digest the theoretical knowledge, enhance the necessary professional skills and improve the theoretical practice ability through the verificationbased experimental teaching.

In this teaching process, every course of experimental teaching is required to have the perfect experimental syllabus, content and guide. Teachers carry out teaching tasks strictly following the experimental syllabus and the progress. According to the progress of curriculum, students are going to orderly finish all experimental contents of the experimental projects under teachers' guidance, or learn themselves by highquality resource sharing. Teachers and students achieve online communication through verification-based experimental teaching platform.

\section{B. The Comprehensive Experimental Teaching}

The comprehensive experimental teaching centers around the basic platform curriculum, and is mainly based on comprehensive and designed experiments. The experimental teaching at this level requires teachers to have rich practical experience and professional training. The teaching tasks are undertaken by teachers who have rich teaching experience and rich practical experience of economics and management to have project cooperation and management consultation with enterprises for many years.

The comprehensive experimental teaching adopts modern teaching methods such as multimedia, information software platform and so on. By simulating realistic economic environment, management environment and investment environment and carrying out comprehensive, designed and innovative experimental projects, the subject frontier is closely connected with the engineering practice and social application practice.

In comprehensive experimental teaching, students can play the role of manager to simulate the running, and verify the running condition from the final management performance, such as industrial management sand-table simulation experiments, financial investment analysis experiments, securities investment analysis experiments, investment and financing analysis, SimTrade foreign trade comprehensive simulation practice, ERP enterprise manufacture operation management platform and other experiments. These comprehensive experimental courses improve students' knowledge mastering of systematicness and interaction, and at the same time enhance their team spirit, communication ability and decision-making ability. 


\section{Research-based Experimental Teaching}

The research-based experimental teaching centers around senior distinctive electives to carry out experimental contents of following three main types: self-designed, research innovative and subject-frontier. Its development is based on research-based teaching team which is made up of backbone teachers, undergraduates and postgraduates.

Research-based experimental teaching makes students enter into laboratory by college students research training plan, which promotes the development and selection of innovative talents. By effective implementation of the training plan of undergraduates' scientific research ability and adoption of twoway choice between teachers and students, undergraduates gradually integrate into teachers' research team. Combined with the available Project of College Students' Innovative Experiment Plan, this type of teaching well combines tutorial system with innovative fund together, and forms hierarchical research group. In this way, tutorial system, innovative fund research plan, laboratory opening and undergraduates' graduation thesis are all integrated together as an organic whole.

The implementation of research-based experimental teaching broadens students' academic vision, enhances students' interest in economic theory, hot topics of economics and management and research of frontier issues, improves students' theoretical level, develops students' research ability of in-depth exploration of scientific problems, and promotes students' being diversified talents.

\section{CONCLUSION}

Research-type universities are the gathering places of science and technology and innovation. The superior R \& D conditions and strong scientific research ability constitute their external characteristics, and the perfect teaching and research echelon and internal innovation driving force constitute the internal characteristics. Centering on developing the research of teaching system construction in research-type universities, this paper explores effective ways to realize all-round promotion of students' comprehensive quality, international vision, scientific spirit, entrepreneurial awareness and creative ability, so as to meet urgent needs of the development of innovation-oriented society. The paper analyzes the present situation of the development of experimental teaching system of economics and management in research universities, and puts forward that the existing experimental teaching system is facing the transformation from single-subject verification to comprehensive design, from knowledge succession to research innovation, from traditional method to combination of new technology, from indoctrination type to enlightening and discussing type of experimental teaching. And it constructs a hierarchical economic management teaching system of research universities which is composed of verification-based experimental teaching, comprehensive experimental teaching and research-based experimental teaching modules, and gives multidimensional paths to improve students' scientific literacy and innovation ability, so as to meet the urgent needs of economic management tip-top talents for the development of innovative society.

\section{REFERENCES}

[1] Zhanjun Wang. What is a Research-Type University [J].Academic Degrees \& Graduate Education, 2003(01):9-11. (In Chinese)

[2] Liang Liu. Development strategy of World-class universities[J]. Education Review, 2011(03):138-141. (In Chinese)

[3] Dongfeng Gao. Demand, Idea and Path of Experimental Teaching Reform of Colleges and Universities in the Information Age [J]. China Higher Education Research,2018(04):93-96. (In Chinese)

[4] Yule Jin, Jing xi Liao. The Cultivation of Tip-top Innovative Talents in American Research University: Experience and Enlightenment [J]. University Education Science,2017(03):43-50. (In Chinese)

[5] Xuanjin Yang, Hongqi Xiong. Empirical Research on Experimental Teaching Informatization in Research Universities [J]. China University Teaching,2018(03):75-78. (In Chinese)

[6] Zhenyuan Qu, Professor and CAHA President. Top-ranking Undergraduate Education Should Focus Students And Learning [N]. Guang Ming Daily,2016-06-28(In Chinese)

[7] Libao Wu. Experience and Inspiration of Undergraduate Education Reform under The "Learning Paradigm" in American Research Universities [J]. Modern University Education, 2017(06):45-52(In Chinese)

[8] Xinpei Zhang, Wenhua Zhao. Joint Development And Inspiration of Research Universities And High-level Think Tank [J]. China Higher Education Research, 2014(08):6-10(In Chinese)

[9] Xiaoping Jiang, Two Dimensions of Innovative Talents Training in First-class universities [J]. Chinese Higher Education, 2018(01):41-42 (In Chinese) 